\title{
"DID YOU BRING NEW SONGS?" THE ROLE OF CONTEMPORARY CATHOLIC MUSIC IN HUNGARY
}

\author{
Kinga PovedÁK \\ Department of Ethnology and Cultural Anthropology \\ University of Szeged \\ Egyetem u. 2, H-6722 Szeged, Hungary \\ E-mail: povedakkinga@gmail.com
}

\begin{abstract}
Contemporary Christian music appeared in Hungary in the 1960s. In a unique period of Hungary when religion was suppressed and rock and roll was denounced, the merging of the two, Christian rock music was even more disapproved during the communist regime. For many, contemporary Christian music was more than simply music; it indicated opposition against the political system. Therefore contemporary Christian music was an alternative music not only from a clerical but also from a political point of view. This article tries to analyze the function of contemporary Christian music in listeners' religious folklife, their experience during listening to contemporary Christian music. ${ }^{1}$

Keywords: congregational music, contemporary catholic music, vernacular religiosity, youth religiosity, religion and modernization
\end{abstract}

\section{INTRODUCTION}

It stands to reason that along the changes of culture, religion changes as well. This statement certainly applies to contemporary processes when the consequences of the infocommunicational revolution continuously appear within the frameworks of vernacular religiosity. The new technical environment generates considerable changes in the forming of communities (e.g. virtual communites), in the ritual practices (e.g. motor bikers' pilgrimage, changing church music) and in the complex vernacular religion. Vernacular religion has always been a synthesized phenomenon. ${ }^{2}$ Along the doctrines of the church in lived religion several beliefs were merged. During the Middle ages the teachings of Christianity were synthesized with the traditions of pagan times, today, however, the characteristics of

${ }^{1}$ This article was written and the research behind it carried out with the help of OTKA grant NK 81502 and No. 68325: "Religions, borders, interactions".

${ }^{2}$ For more details see Leonard Norman Primiano entry in: Brunvald 1996: 620-621, also Primiano 1995. 
mass culture incorporate into religious practices. Among all technical changes and transformations the most noticeable is the penetration of mass media into the religious sphere. As Hoover formulates if "Religion today is much more a public, commodified, therapeutic, and personalized set of practices than it has been in the past. At the same time, the media (movies, radio, television, print and electronic media, and more) are collectively coming to constitute a realm where important projects of the »self « take place - projects that include spiritual , transcendent, and deeply meaningful »work.« This means that rather than being autonomous actors involved in institutionalized projects in relation to each other, religion and media are increasingly converging. These are meeting on a common turf: the everyday world of lived experience." ${ }^{3}$ As a consequence of mass media, not only the technical environment has changed, but the ethos of consumer civilization rapidly spread resulting a significant shift in believers' world-view and way of thinking.

"The Consumer Society is a formation system: it forms us and our behaviour. It is also an information system: it informs us as to our identity and as to the status of our world. Its influence is felt in every dimension of our lives, and each dimension echoes and mirrors the others. "4 Therefore, we can trace once again a certain synthetisation as through the appearance of new communicational channels the content of the forwarded message partly changed as well, supporting Marschall McLuhan's theory of "technological determinism". 5 The Roman Catholic Church tried to respond to these changes among others and addressed reforms at Vatican Council II comprehending and corresponding to the signs of time by representing a "partner or companion attitude" towards modernity. The Catholic Church did not denounce modernity but under the aegis of the key term "aggiornamento" she tried to approach modern times and adapt Catholicism to modernity. ${ }^{6}$

However, the liberalization following Vatican II conjured ambivalent reactions and increasing inner pressure. While those taking notice of the peculiarities of the new technological and cultural circumstances, and also the newer generations welcomed the re-

\footnotetext{
${ }^{3}$ HoOver 2002: 2.

${ }^{4}$ Kavanaugh 2006: 4.

${ }^{5}$ Marshall McLuhan published his book Gutenberg Galaxy in 1962. The McLuhaninan 'technological determinism' probably had more critics than supporters. As a finding of his research he concluded in the first chapter of his book the much-quoted statement of "the medium is the message" meaning that the type of medium predestinates the content of the message. ,... it is sometimes a bit of a shock to be reminded that, in operational and practical fact, the medium is the message. This is merely to say that the personal and social consequences of any medium - that is, of any extension of ourselves - result from the new scale that is introduced into our affairs by each extension of ourselves, or by any new technology...This fact, characteristic of all media, means that the 'content' of any medium is always another medium." MCLuHAN 1964: 23.

${ }^{6}$ Based on MacSweeney and Hellemans we can differentiate 4 major periods in modern ecclesiastical history. The different periods are characterized by different attitudes towards modernity. The first period from the French Revolution until 1878 is characterized by total rejection of a licentious and impermenent disorder. From 1878, that is from Leo XIII until the Vatican Council II a competition against a hostile order is the most important feature. The period shortly after Vatican II is characterized by an alliance, while the last period from 1978 is characterized by an alternative voice. These, in turn, are bound up with four self-images of the church: (1) victim of temporary, revolutionary agitation; (2) counterpower fighting a fearsome enemy; (3) partnership with modernity; (4) embattled minority group. These also link with the mirror images of how the church perceived modernity: (1) sinful interruption; (2) secular power; (3) partner; (4) social context hostile to the church. Hellemans 2001.
} 
forms as the introduction of the "new language" of the church; others considered Vatican II as the generator and accelerator of secularizing tendencies and apparently leading to the loss of the traditional image of the Roman Catholic Church. ${ }^{7}$ This ambivalent approach is prevalent in the attitude toward contemporary forms of liturgical and church music. New techniques and the analysis of media very often stagnates within the frames of visuality and a significantly smaller attention is paid to musicology, although one of the most important characteristics of youth subculture is the expression of identity through music. As Gordon Lynch puts it "Music has, in the past, been an important cultural resource and practice for religious communities [...] music has served a number of functions, such as reinforcing religious identities, establishing a sense of collectivity within religious groups, acting as a means of theological expression, celebration, protest, and lament, providing a subcultural resource and practice against dominant religious identities and orthodoxies, and serving as a focus and stimulus of religious experience and sentiment." 8

In this study I intend to give a complex analysis of the contemporary Catholic music phenomenon. I would like to illuminate the role of contemporary Catholic music during socialist Hungary and after the collapse of state-socialism. I also look at how this trend of music defines the vernacular religiosity and religious experiences of the young.

Due to the complexity of the subject matter I shall use the methodology and perspectives of several disciplines. Firstly, through a comparative analysis based on historical sources and oral history, while the analysis of the contemporary phenomenon is understood through semi-structured interviews, questionnaire and the analysis of online forums and blogs.

\section{APPLIED TERMINOLOGY}

In our days contemporary Christian music is a miscellaneous and complicated phenomenon in both the international and the Hungarian scenario. You can find all musical products from liturgical Taize songs to rap songs with a Christian content. Due to this variety and complexity contemporary Christian music cannot be analyzed and understood as a single genre. Scientific literature has not agreed on how to define contemporary Christian music yet. Some consider the single defining characteristic of contemporary Christian music to be the faith of the artists who produce it, others the intention behind creating a piece of music, again others judge on the basis of the songs' content. ${ }^{9}$ When I refer to contemporary Christian music I mean songs with a content closely related to Christian teachings and ideology performed by Christian artists with liturgical, worship or evangelizing purposes. We can make further typologization based on musical styles, different denominations, and spiritualities. There are also significant differences between the tremendous entertaining industry built around American contemporary Christian music and the Hungarian/European

\footnotetext{
${ }^{7}$ Gamber 1975: 48-61.

${ }^{8}$ LYNCH 2006: 482.

${ }^{9}$ For a summary see PovedÁk 2009.
} 
context showing little or no sign of commercialism. ${ }^{10}$ "The lines between sacred and secular became increasingly blurry as the Christian music industry promoted a consumer oriented culture that copied, even in some sense usurped, many functions of institutional religion. Concerts became worships services or evangelistic meetings. Consumer commodities (CDs, T-shirts, and other paraphernalia) became symbols representing religious faith. For some evangelical fans, social rituals, like going to a Christian concert or listening to a gospel recording on headphones, could qualify as a religious experience as much as attending church service with a local congregation." 11

The present paper intends to analyze contemporary Hungarian Catholic music, which primarily consists of liturgical and evangelizing music (and very often the evangelizing events take place in the church as well). It is also important to point out that there are no clear-cut borders. Contemporary Christian music is not associated with only one denomination; therefore it is ecumenical in the strict sense of the word. For instance, the music of the Catholic charismatic renewal movement is more likely to use contemporary Protestant church music rather than the traditional Catholic heritage. Consequently, in this paper I will stick to the expression of contemporary Christian music as it is different to make distinctions along denominational lines within the domain of contemporary Christian church music.

\section{HISTORICAL CIRCUMSTANCES}

The appearance of Hungarian contemporary Christian music - and therefore the analysis of the phenomenon as well - is closely related to the circumstances of the Kádár-system's socialist dictatorship. The Kadarist cultural policy strictly censored the western influx of mass culture. Among socialist repression, the new musical style moving young people was considered to be especially dangerous. In the 1950s such processes evolved in western popular music that had great influences beyond popular music and generated changes in popular culture, politics and in vernacular religiosity as well. Meanwhile, the emerging rock'n'roll completely changed popular music and transformed fashion and trends; having a group formulating power it created subcultures as well. Some of these subcultures had countercultural elements as they turned against the actual ruling elite adding a political tone to the phenomenon. The political ruling power stood up against it and tried to squeeze their socially self-organized structures. The centrally controlled and supervised cultural life did not allow for initiatives towards small-communities ${ }^{12}$ as the party leaders knew it well, as Tomka highlighted: "community means power as it might lead to independent thinking or even opposition". ${ }^{13}$ Popular music and rock'n'roll entered into the realm of religious life, too. Therefore, the formation of

\footnotetext{
${ }^{10}$ Naturally, the contemporary Christian music in the USA is not unified either. From the 1970s the contemporary Catholic music stream appeared refusing the commercialized contemporary Christian music scene. Most of these artists operate without the benefit of a record label or major sponsor and sacrifice much to minister and entertain with their music. Some are in full-time ministry, but most are juggling jobs and family to do their ministry.

${ }^{11}$ RoMANOWSKi 2000: 110.

${ }^{12}$ VALUCH 2006: 149

${ }^{13}$ Tомка 2005: 173 .
} 
contemporary Christian music began. Several choirs and small communities evolved being organized around this new church musical style. Since the political system forced churches in a dependable position, consequently the phenomenon, which was considered "prohibited" or "tolerated" ${ }^{14}$ by politics, had to be treated in a similar manner by churches as well. This might be a partial answer why the leaders of the Catholic Church tolerated contemporary Christian music and the forming of small communities, yet at the same time were rather concerned about it. It is also important to point out that in several cases these new musical groups and choirs were enhanced and helped by the so-called "problematic/rebellious" Catholic priests. The beginnings in Szeged around the 1970s are a good example.

"There was fr. Tibor Nagy of whom Miska ${ }^{15}$ was continuously laughing at. $\mathrm{He}$ was called "Tubi Tibi" because he was a peace priest. So this fr. Tibor Nagy helped us to get started with our guitar music, so under his protection we experienced no insults." 16

"Fr. Laci Galgóczi invited us to help him in religious education and in pre-marital courses. [...] He began organizing that he knew the priest at Csorvás, at Szolnok or Szabadka. A new priest's first mass here, there, he would organize everything, we just had to go and play the music. [...] First we did not want to go. We hadn't played for a long time but he was very committed and talked us into it. Then I told my friend, let's go, give him what he wants we might get away more easily. That is the story of us starting to play and we continued to play for 20 years, until Sali's death. [...] Laci Galgóczi told us to go to Röszke, so as to be out of sight. It was fr. Galgóczi’s idea as Sali was a law student at that time $[\ldots]^{\prime \prime 17}$

The fear of political leaders was not without any reason, since contemporary Christian music was suitable for motivating the young and to enhance the formation of youth groups. In the Danube Curve from 1971 in Kismaros, later in Nagymaros, Youth Days were organized illegally by enthusiastic young priests (Ferenc Tomka, Miklós Kerényi or Béla Balázs) and the festival still attracts several thousand young people even after 40 years. ${ }^{18}$ Sándor Sebők, the parish priest of Fót said the followings about Jenő Sillye, the most wellknown contemporary Catholic musician: "Today it is obvious that the renaissance of the Hungarian Catholic Church evolved in the Danube curve. [...] Many believers felt strange about this new music but a few months later they couldn't wait for the holy masses served with guitar music. This new music had a community-forming power, those who heard it, felt that the liturgy belongs to them even more." 19

\footnotetext{
${ }^{14}$ Reference to György Aczél's "3 T theory", according to which all cultural products and actors fall into either of the following categories "prohibited", "tolerated" and "allowed" (the Hungarian equivalent of each word starting with a ' $T$ ').

${ }^{15}$ Mihály Gubik, the parish priest Bácsbokod, who supported contemporary Christian music, and even organized a youth festival in the settlement.

${ }^{16}$ 53-year-old man, Szeged (13.10.2009).

${ }^{17}$ 52-year-old woman, Szeged (09.10.2009).

${ }^{18}$ See Kamarás 1989; BodnÁr 2002.
}

19 BODNÁR 2002: 29. 
The ambivalent attitude of the church is obviously not only the result of the strong political measures. The secularizing tendencies of Hungarian society became stronger in the officially atheist Hungary. Some believe that the reason, among the unique political circumstances and the spreading of rationalizing world views, lies in the out-dated and dusty 'language' of the church. ${ }^{20}$ Quoting the words of Gyula More, the Christian churches have to meet the challenges among modern circumstances and provide answers. First, in what language they formulate their message and what the plausibility structure of that in contemporary society is, where they do not have the 'authority of the scribes' addressing illiterates, rather through the spreading of mass communication instruments they convene a 2000-year-old-message to semi- and well-educated groups. ${ }^{21}$

Many consider contemporary Christian music to be the "new language" of the Catholic Church, through which communicating the message of Christianity is a lot easier and more effective, than it might be through the means of traditional folk hymns. At the same time, others see the appearance of a popular musical trend within traditional churches which is rooted in liberal grounds and they disregard contemporary Catholic music based on aesthetics.

Contemporary Christian music was considered to be a twofold alternative tendency. First, from a political point of view as it belonged to counter-culture created by beat music. Second, because being religious in the Kádár-era socialism alone meant an opposition to the current political system.

"During that time we met Fr. Miska Gubik, who was a parish priest in Bácsbokod opposing "stupidity and communism" [...] Miska especially supported this new style but in a radical way. He provoked the police officers on purpose [...] He organized a youth meeting in Bácsbokod. He began by welcoming everyone, the informants as well, and asked them to only note down what was said so there should be no problem about that". ${ }^{22}$

The statement of János Köbányai about beat music is especially true for contemporary Christian music. "...going to beat concerts did not only mean the attendance to a show, but was also a demonstration of affiliation [...] and if the young do not form organized communites in a controlled form, it is most likely demonstrated by deviant behaviour forms". ${ }^{23}$ Consequntly, the early stages of contemporary Christian music in Hungary were strictly controlled by political authorities.

"It was around 1975-76 that we heard about a »pop-festival« at Nagymaros where people playing this kind of music gathered and you could play or learn music and so on. During the travel young people joined us in the "Keleti" Station and we started talking. They asked for all kinds of personal information such as where we came from, how long have we known about this, who roped us in and so on. I was so naïve that I almost

\footnotetext{
${ }^{20}$ Morel 1983; Morel 1995; Morel 1998.

${ }^{21}$ Morel 1998: 82-83.

22 53-year-old man, Szeged (13.10.2009).

${ }^{23}$ KöBÁNYAi 1986: 35.
} 
told them everything but in a certain moment for God's impulse I started to say false things like »I don't have the faintest idea, I don't know who will be there, who he or she is or so. Come on my friends, we'll see it. This is the first time that I'm here also!« And when they saw that they couldn't get any useful information they left us." ${ }^{24}$

With these actions authorities contributed to the samizdat nature of contemporary Christian music. The contemporary Christian music and songs gained a certain counterculture character as they were rejected from official culture and from official media. The songs often spread orally in the forms of variants.

"After I got to Budapest it was my duty to collect sheet music, because by that time Jenő and his friends were well known here in Szeged as well. Whenever I came home aunt Emese asked me: »Did you bring new songs?«" 25

On the other hand, this political attitude was strengthened by the fact that contemporary Catholic music was handled as an "alternative" religious movement, which endangered traditions due to its "liberal roots" and could subvert the religious life and rituals. ${ }^{26}$

\section{THE ROLE OF NEW MUSIC IN YOUTH RELIGIOSITY}

The appearing pluralism in ideology and value-system after the fall of socialism greatly changed the character of contemporary Christian music as well. On the one hand, significant quantitative growth can be observed which is well demonstrated by the increasing number of records from the most significant singers ${ }^{27}$ and church choirs as well. On the other hand, due to this "mass production" of contemporary Christian music we can only give the main tendencies and the most important parameters in this study. In the meanwhile, new generations appeared for whom "beat" music holds a different symbolic - religious and certainly not political - content than it used to have in the case of the generations of 1960s and 1970s. By now contemporary Christian music does not symbolize the counter-culture and value system of the listeners who used to be in contrast with the official politics, rather religious nationalism, the preserving of national identity can be traced on occasions ${ }^{28}$ and the public confession of faith or evangelizing are also often emphasized. Meanwhile, the international hippie-movement also winded and lost its rebellious character giving place for new, fashionable entertaining music styles that have a much less social content. At the same time, however, several members of the "legendary" first generation aer still active,

\footnotetext{
${ }^{24}$ 53-year-old man, Szeged (13.10.2009).

25 53-year-old man, Szeged (13.10.2009).

${ }^{26}$ Cardinal László Lékai, the archbishop of Esztergom, did not support contemporary Catholic music before 1980 as he found the small communities centered around this music to be dangerous to the church-state

${ }^{27}$ The first record released was Jenö Sillye's “Kristályóriás” [Crystal-giant] in 1984.

${ }^{28}$ After the political changes of 1989, the life and situation of minority Hungarians living outside Hungary gained increasing interest in the lyrics of contemporary Catholic music.
} relationship. 
new styles (Christian rap, disco, metal, etc.) appeared diverging contemporary Christian music. Those who started to play the music as young teens in the 1960s and 1970s for now became grandparents. The Nagymaros Youth Festival has remained one of the greatest Christian youth festivals for the past 40 years, however, new contemporary Christian and Gospel festivals appeared. ${ }^{29}$ A significant number of the new bands and singers produce evangelical or worship music for outdoor/out-of-church activities (effected by American inspiration) and not for liturgical functions. Besides, certain famous singers of "worldly" pop music also released songs with Christian content. ${ }^{30}$ These impoverishment processes have also effected the songs' aesthetic level. Contemporary Christian music became so diverse in post-socialist Hungary that the classification became necessary.

We must take into consideration that together with the technical changes the mentality, world view and attitudes of new generations have also transformed. The most important characteristic of the Generation Y or the so-called millennial generation (born after 1982) is the usage of internet, online communication and connecting to virtual communities. All these characteristics have increasing importance in the daily life, free time and cultural habits of the members of Generation Y. ${ }^{31}$ All these characteristics are increasingly present in the everyday and leisure activities, the religious practices and consumption of cultural products of Generation Y. No matter how much their culture and communal rites are changing, the attitude towards music remains the same. All the interviews and questionnaires I conducted with university and college students confirm the aforementioned thesis of Gordon Lynch. Interlocutors emphasized the community-building, identity-strengthening role of contemporary Christian music and the connection between music and the depth of their religious experience. The young emphasized that new music was much easier to understand and interpret as opposed to traditional folk hymns. Their opinion supports Morel's thesis concerning the problem of the "new language" in Catholicism. ${ }^{32}$

"This modern music is easier to understand, to comprehend and therefore it can become more personal. Everyone in church can participate while in case of a Tallis piece it is not true." 33

"These songs are written in our language, written for the youth and sometimes composed by us." 34

"These are folk hymns for us. As Christian youth we can relate to this, this music has meaning for us. [...] The community is very important in these songs. These songs serve as our folk hymns. This can convene a message to the younger generation and we can participate and sing these songs. This is articulated in our language." 35 2000 .

${ }^{29}$ Both the "Ez az a nap!" [This is the Day!] festival and the Gospel Festival at Solymár was launched in

${ }^{30}$ For instance Ákos, Zámbó Jimmy, Lovasi András \& Bognár Szilvia.

${ }^{31}$ Brasher 2004; SAVAge - Collins-Mayo - Mayo - Cray 2006.

${ }^{32}$ Morel 1998.

33 25-year-old man, Szeged (08.03.2010). Thomas Tallis (c. 1505-1585) was an English composer and church musician. He is considered among the best of England's early composers.

${ }^{34}$ 24-year-old man, Szeged (08.03.2010).

${ }^{35}$ 20-year-old man, Szeged (25.02.2010). 
"Unfortunately, today we welcome believers in the church with such music that they never listen to - at least most of them - and which is strange to them. This way the Holy mass will not be attractive for them. However, the biggest problem is that they will not discover Christ. If God bent down to man then the Church, the miraculous body of Christ, has to do the same. Whether by »packing « the gospel into popular music [...] But why would it be impossible to create new styles? For instance, by mingling the elements of classical and popular music or somehow? [...] These songs deal with us, our real world and are alive today while Gregorian or folk hymns aren't. Of course it cannot be expected from Gregorian or folk hymns, as those are fruits from ancient times. Why can't we be at home in our world as Christians? Is it necessary for Christianity to only be enthusiastic about the past and completely ignore the present? $?^{36}$

According to them the happiness and the youthful dynamism of contemporary Catholic music could fill the churches while traditional folk hymns are too sorrow and mournful. ${ }^{37}$

"The traditional folk hymns are too sorrowful, dolorous and grievous. It is not a great experience musically either. Usually the songs are yowled. And not to mention the »wonderful« lyrics. There is no young dynamics in it. For me Christianity is not about grieving rather about happiness and the faith in resurrection." 38

"Spirituality is rooted in these songs. It shows the way to God for me and it touches my feelings. If we sing these songs together in a nice way, not with dilettantism it affects people a lot. It can be a lot more powerful as folk hymns [...] These singings together at the yearly retreats are very extraordinary experiences for me. It might seem childish when 60-70 people stand up and sing these songs with motions. However, I feel these bind us together, it gives me a sense of belonging..." 39

\section{CONCLUSION}

Although this paper did not aim to evaluate but to analyse contemporary Christian music it cannot be left without consideration that holy masses have been giving visual and audible aesthetic experience as well. However, the sense of taste differs individually. While they mainly agree on the object of their faith, the moral and behavioural norms required by their church (naturally, there could be significant differences on the level of vernacular religiosity), the lived religion with the related private and public rituals greatly differ. Thus the attitudes towards contemporary Christian music are ambivalent among laic and

\footnotetext{
${ }^{36} \mathrm{http} / / /$ igen.hu/egyhaztaji/397-legyenek-e-gitaros-kantorok.html Last access: 03.03 .2011

37 "The situation is that it seems people like this music as the »Doobie doobie doo « holy masses are fully crowded with young so that the walls crackle. I don't like it either but others seem to..." http://forum.index.hu/ Article/showArticle?na_start $=0 \&$ na_step $=30 \& \mathrm{t}=9081894 \&$ na_order $=$ Last access: 12.02 .2011 .

${ }^{38} 22$-year-old man, Szeged (14.04.2010).

39 23-year-old woman, Szeged (15.04.2010).
} 
cleric persons as well. As there were priests in the 1960-70s realizing the needs of youth's religious life and organizing communities with the help of contemporary Christian music, there are also similar persons and attempts today. Others believe that there is no need for allurement in order to compensate the secularizing tendencies and attract the youth to the church. In the past decades the theological arguments have given place to aesthetic-based debates. Meanwhile the function of the music has also changed. While in the years of state socialism the "twofold alternative" contemporary Christian music represented religious and political identity at once, after 1989 it has been primarily functioning as worship music inside and outside the church building.

\section{LITERATURE}

BoDNÁR Dániel

2002: Lélektöl lélekig [From soul to soul]. Budapest: Múzik Bt.

BRASHER, Brenda E.

2004: Give me that online religion. New Brunswick: Rutgers University Press.

BRUNVALD, Harold Jan (ed.)

1996: American Folklore. An Encyclopedia. New York \& London: Gartland Publishing, Inc. $620-621$.

GAMBER, Klaus

1975: A liturgia reformjának problémái [The poblems of liturgical reform], in: SzENNAY, András (ed.), Régi és új a liturgia világából. Budapest: Szent István Társulat. 48-61.

Hellemans, Staf

2001: From "Catholicism against modernity" to the problematic "modernity of Catholicism". Ethical Perspectives 8 (2), 117-127.

Hoover, Stewart M

2002: The cultural construction of religion in the media age, in: Hoover, Stewart M. - Clark, Lynn Schofield (eds.), Practicing Religion in the Age of the Media. Exploration in Media, Religion and Culture. New York: Columbia University Press, 1-7.

KAMARÁs, István

1989: Lelkierömü Nagymaroson [Spiritual powerplant at Nagymaros]. Budapest: VITA.

KaVANAUgh, John F.

2006: Following Christ in a Consumer Society. The Spirituality of Cultural Resistance. New York: Orbis Books, Maryknoll.

KöBÁNYAI, János

1986: Beatünnep után [After Beat-feast]. Budapest: Gondolat.

LYNCH, Gordon

2006: The role of popular music in the construction of alternative spiritual identities and ideologies. Journal for the Scientific Study of Religion 45 (4), 481-488.

Mcluhan, Marshall

1964: Understanding Media: The Extensions of Man. New York: Mentor.

Morel, Gyula

1983: Church in Transition. Vienna: Ungarisches Kirchensoziologisches Institut UKI.

1995: A jövö biztosabb, mint a múlt [The future is safer than the past]. Budapest: Egyházfórum.

1998: Egyház a kommunikációs társadalomban - a jelentés és a jelentőség krízise [The Church in the communicational society - The crisis of meaning and significance], in: МÁтÉ-ТótH, András - JAHN, Mária (eds.), Studia Religiosa. Tanulmányok András Imre 70. születésnapjára. Szeged: Bába és Társa Kiadó. 80-89. 
PovedÁk, Kinga

2009: Gitáros apostolok. A keresztény könnyüzene története és értelmezése [Apostles with guitar. The history and analysis of contmeporary Christian music]. Szeged. (unpublished paper)

PRIMIANO, Leonard Norman

1995: Vernacular religion and the search for method in religious folklife. Western Folklore 54 (1), 37-56.

RoMANowsKi, William D.

2000: Evangelicals and popular music: The contemporary Christian music industry, in: ForBEs, Bruce David - Mahan, Jeffrey H. (eds.), Religion and Popular Culture in America. Berkeley: University of California Press. 103-123.

SAVAge, Sara - Collins-Mayo, Sylvia - MaYo, Bob - Cray, Graham

2006 Making Sense of Generation Y. The World view of 15-25-year-old. London: Church House Publishing.

OMKA, Ferenc

2005: Halálra szántak, mégis élünk! [We were sentenced to death, still we are alive!]. Budapest: Szent István Társulat.

VALUCH, Tibor (ed.)

2004: Magyar társadalomtörténeti olvasókönyv 1944-töl napjainkig. [Reader to the social history of Hungary from 1944 to the present day] Budapest: Argumentum - Osiris. 